\title{
Technical Efficiency of Sole Maize and Maize/Melon Intercrop in Osun State, Nigeria
}

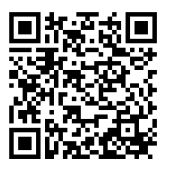

\author{
Baruwa OI* and Familusi IG \\ Department of Agricultural Economics, Obafemi Awolowo University, Ile-Ife, Nigeria
}

Submission: November 29, 2018; Published: August 29, 2019

"Corresponding author: Baruwa OI, Department of Agricultural Economics, Obafemi Awolowo University, Ile-Ife, Nigeria

\begin{abstract}
Intercropping has been found out to have enormous economic advantages for the farmer, although with some possible adjoining disadvantages attributable to competition and lack of adequate management. This study therefore analyzed and compared the technical efficiencies of sole maize and maize/melon intercrop farmers in Osun State with a view of determining the factors that influences it. Purposive sampling was used to select 47 respondents each for sole maize and maize/melon intercrop system. Stochastic frontier production function was used to estimate the technical efficiencies. The study revealed that the mean technical efficiency of maize/melon intercrop farmers was higher than that of the sole maize farmers. Costs of land, labor and implement were the factors affecting the sole maize farmers' efficiency, while the maize/melon intercrop farmers' efficiency was significantly determined by costs of land, labor and capital. No significant factor determines inefficiency for sole maize farmers. However, land security and extension visit were the major significant inefficiency factors found out to reduce the inefficiencies of maize/ melon intercrop farmers in the study area. It is recommended that famers in the study area should venture into the intercropping of maize and melon more than sole maize cropping; government should strengthen land security and give adequate motivation to extension agents to visit farmers more in order to increase their technical efficiencies.
\end{abstract}

Keywords: Technical efficiency; Sole maize; Maize/melon intercrop; Stochastic frontier production

\section{Introduction}

The growth of two or more crop species simultaneously in the same field during a growing season is known as intercropping [1]. Numerous literatures have often argued in favor of one cropping system over the other [2-5]. It was reported that farmers intercropped for varied reasons [6], including insurance against crop pests, yield increment, weed control and high monetary returns to the farmers. Intercropping is a common practice in tropical developing countries because of its several advantages $[7,8]$ and maize and cassava intercrop has been described as the most prevalent and most productive enterprise with highest net margins in southern Guinea savanna ecology [9].

The cultivation of maize in combination with other crops is a common practice in the tropics [10]. About $73 \%$ of the maize in Nigeria is under intercropping [11,12]. Several studies have been carried out on monoculture maize and melon as influenced by intra-row spacing $[13,14]$, The incorporation of 'egusi' melon into maize/cassava intercrop at the right time has been reported to be more profitable and more environmentally friendly [15]. However, it was also reported [16] that the intercropping increased competition between crops and weeds for nutrients and light. In some cases, the output of one crop may be increased through a decline in the production of the other, a situation referred to as 'dominant' and 'dominated', respectively [17]. In some other cases an increase in output of one crop could help to bring about an increase in output of the other crop; this situation is referred to as 'mutual co-operation' [18]. Therefore, the need arises to determine the technical efficiency of sole maize and maize/melon intercrop farmers in Osun State in order to ascertain how efficient each cropping system is and compare to be able to determine which has technical advantage over the other in the study area.

The objectives of the study were to determine the technical efficiency of sole maize and maize/melon intercrop farmers and factors affecting technical efficiency of sole maize and maize/melon intercrop farmers.

\section{Materials and Methods}

\section{Study area}

The study was performed in Osun State, South-west, Nigeria. It is located between Longitude $7.0^{\circ} \mathrm{N}$ and $9.0^{\circ} \mathrm{N}$, and latitude $2.8^{\circ}$ $\mathrm{E}$ and $6.8^{\circ} \mathrm{E}$ with thirty Local Government Areas (LGAs). Osun State is an inland state with Osogbo as the capital.

A total of 94 farmers were purposively samples with the assistance of extension agents from Osun State Agricultural Development Program (OSSADEP) from the two LGAs namely: Atakunmo- 
sa West and Iwo based on the predominance of maize and maize/ melon intercrop in these LGAs relative to the rest. Forty-seven questionnaires were administered on each of Sole-maize farmers and Maize/Melon intercrop farmers.

\section{Data collection}

Primary data were collected from respondents with the aid of structured questionnaire. Information collected includes socio-economic characteristics of the respondents, farm characteristics; quantities and prices of inputs and output in the area during the farming season.

\section{Methods of data analysis}

The technical efficiency of both sole maize and maize/melon intercrop and the inefficiency factors were estimated with stochastic frontier production function. The model is specified as follows:

$\begin{aligned} \ln \left(Y_{i}\right) & =\beta_{0}+\beta_{1} \ln \left(X_{1}\right)+\beta_{2} \ln \left(X_{2}\right)+\beta_{3} \ln \left(X_{3}\right)+\beta_{4} \ln \left(X_{4}\right)+V_{i}-U_{i}(1) \\ \text { where: } & \\ Y_{i} & =\text { Revenue (N) } \\ X_{1} & =\text { Cost of land } \\ X_{2} & =\text { Cost of labor (N) } \\ X_{3} & =\text { Capital sourced ( } \mathrm{N}) \\ X_{4} & =\text { Implement cost ( } \mathrm{N}) \\ V_{i} & =\text { random or stochastic disturbance term. This captures ran- }\end{aligned}$ dom variables which are assumed to be identically, independently and normally distributed with zero mean and a constant variance $\left(\sigma v^{2}\right)$.

$U_{i}=\delta_{0}+\delta_{1} Z_{1}+\delta_{2} Z_{2}+\delta_{3} Z_{3}+\delta_{4} Z_{4}+\delta_{5} Z_{5}+\delta_{6} Z_{6}+\delta_{7} Z_{7}+\delta_{8} Z_{8}+\varepsilon_{i}$

where:

$Z_{1}=$ Age of respondent

$z_{2}=$ Gender of respondent (female $=1$; otherwise $=0$ )

$Z_{3}=$ Family size of respondent

$Z_{4}=$ Years of education of respondent

$Z_{5}=$ Membership of cooperative society/association (Yes = 1 ; otherwise $=0$ )

$Z_{6}=$ Years of farming experience
$Z_{7}=$ Land security level (Very low $=1$, Low $=2$, High $=3$, and Very high $=4$ )

$Z_{8}=$ Extension visit $($ Yes $=1$; otherwise $=0)$

$\delta_{0}, \delta_{i}=$ parameters that were estimated

$\varepsilon_{i}=$ random disturbance term

The technical efficiency of an individual farm is defined in terms of the observed output $\left(\mathrm{Y}_{\mathrm{i}}\right)$ to the corresponding frontier output $\left(\mathrm{Y}_{\mathrm{i}^{*}}\right)$ given available technology, that is:

$$
\begin{gathered}
T E_{i}=Y_{i} / Y *=f\left(X_{i} ; \beta_{i}\right) \exp \left(V_{i}-U_{i}\right) / f\left(X_{i} ; \beta_{i}\right) \exp (V) \\
T E_{i}=\exp \left(-U_{i}\right)
\end{gathered}
$$

So that, $0 \leq T E \leq 1$. If $T E=1$, the farm is said to be technically efficient and its output is on the frontier. Otherwise, that is, if $\mathrm{TE}<1$, the farm is technically inefficient because it could have produced more outputs with the given level of inputs irrespective of input prices.

The estimates for all the parameters of the stochastic frontier production function and the inefficiency model were simultaneously obtained using the computer program Frontier 4.1 [19].

\section{Results and Discussion}

\section{Estimates of the parameters in the stochastic produc- tion frontier function}

Table 1 presents the maximum likelihood estimates of the stochastic production frontier model for both sole maize and maize/ melon intercrop farmers. The results revealed the presence of technical inefficiency among both group of farmers in the study area based on the significance of gamma and the Likelihood Ratio $(\lambda)$ test.

The estimated elasticities of the independent variables revealed that costs of land $(-1.62)$, labor $(-20.00)$ and implement $(-3.16)$ were the significant factors affecting the level of production for sole maize farmers. Cost of land was significant at $10 \%$ and reduces technical return as its level increases for sole maize farmers. This is because the managerial ability of most of the farmers becomes inefficient with increasing farm size. The costs of labor and implement, both significant at $1 \%$, also reduce the level of output with increasing use. This may not be unconnected with the fact that as more labor and implements becomes available, utilization becomes inefficient as a result of excess supply.

\begin{tabular}{|c|c|c|c|c|c|c|c|}
\hline & & \multicolumn{3}{|c|}{ Sole Maize } & \multicolumn{3}{|c|}{ Maize/Melon Intercrop } \\
\hline & Variable & Coefficient & SE & t-ratio & Coefficient & SE & t-ratio \\
\hline b0 & Constant & 106.36 & 1 & $106.46^{* * *}$ & -145.38 & 1 & $-145.91^{* * *}$ \\
\hline b1 & lnland & -1.62 & 0.99 & $-1.65^{*}$ & -3.33 & 1 & $-3.32^{* * *}$ \\
\hline $\mathrm{b} 2$ & lnlabour & -20 & 0.97 & $-20.63^{* * *}$ & 21.7 & 0.87 & $24.93^{* * *}$ \\
\hline b3 & Incapital & 1.19 & 0.97 & 1.22 & 11.5 & 0.82 & $14.01^{* * *}$ \\
\hline
\end{tabular}

Table 1: Determinants of technical efficiency and inefficiency among sole maize and maize/melon intercrop farmers in the study area. 
Annals of Reviews and Research

\begin{tabular}{|c|c|c|c|c|c|c|c|}
\hline b4 & lnimplement & -3.16 & 0.98 & $-3.24^{* * *}$ & -0.77 & 0.97 & -0.79 \\
\hline \multicolumn{8}{|l|}{$\begin{array}{l}\text { Inefficiency } \\
\text { Model }\end{array}$} \\
\hline d0 & constant & 0 & 1 & 0 & 2.15 & 0.58 & $3.73^{* * *}$ \\
\hline $\mathrm{d} 1$ & Age & 0.02 & 0.15 & 0.15 & -0.01 & 0.02 & -0.43 \\
\hline $\mathrm{d} 2$ & Sex & 0.02 & 0.99 & 0.02 & -0.21 & 0.22 & -0.97 \\
\hline d3 & Family size & -0.11 & 0.89 & -0.12 & -0.03 & 0.06 & -0.57 \\
\hline $\mathrm{d} 4$ & $\begin{array}{l}\text { Years of educa- } \\
\text { tion }\end{array}$ & -0.04 & 0.19 & -0.21 & -0.03 & 0.03 & -0.92 \\
\hline d5 & $\begin{array}{l}\text { Cooperative } \\
\text { member }\end{array}$ & 0.01 & 0.99 & 0.01 & -0.12 & 0.29 & -0.4 \\
\hline d6 & $\begin{array}{l}\text { Farming expe- } \\
\text { rience }\end{array}$ & -0.01 & 0.14 & -0.05 & 0.02 & 0.02 & 1.14 \\
\hline d7 & Land security & 0.33 & 0.68 & 0.49 & -0.21 & 0.1 & $-2.17^{* *}$ \\
\hline d8 & Extension visit & -0.04 & 0.99 & -0.04 & -0.2 & 0.06 & $-3.31^{* * *}$ \\
\hline sigma2 & & 0.17 & 0.28 & 0.59 & 0.09 & 0.02 & $5.70^{* * *}$ \\
\hline gamma & & 1 & 0.21 & $4.85^{* * *}$ & 1 & 0 & $26039.36^{* * *}$ \\
\hline $\begin{array}{l}\log \text { likelihood } \\
\text { function }\end{array}$ & 3.41 & & & 15.21 & & & \\
\hline $\begin{array}{l}\text { LR test of the } \\
\text { one-sided error }\end{array}$ & 18.41 & & & 35.14 & & & \\
\hline
\end{tabular}

Source: Field survey, 2016.

$\left({ }^{* * *}\right),\left({ }^{* *}\right)$, and $\left({ }^{*}\right)$ denote significance at 1,5 , and $10 \%$ respectively, $(\Delta)$ indicated dummy variables, SE is standard error.

For the maize/melon intercrop farmers, the technical efficiency was significantly influenced by cost of land (-3.32), labor (24.93) and capital (14.01). A unit increase in the cost of land, leads to 3.32 reductions in output. For labor and capital, a percent increase in their costs leads to an increase of 24.93 and 14.01 respectively in the level of outcome.

\section{Technical inefficiency analysis}

Table 1 presents the factors that statistically influence the inefficiency of sole maize and maize/melon intercrop farmers in the study area. For the sole maize farmers, no significant variable which is not consistent with the findings of some studies [20,21], while only land security $(-2.17)$ and extension visit $(-3.31)$ were the major determinants of inefficiency for the maize/melon intercrop farmers in the study area significant at $5 \%$ and $1 \%$ level.
This implies that as land security increases, technical inefficiency decreases. Also, as extension visit increases, the technical inefficiency reduces thereby leading to increasing technical efficiency of the maize/melon intercrop farmers.

\section{Technical efficiency analysis}

From Table 2, the mean predicted technical efficiency for the sole maize farmers was $69 \%$ lower than that of the maize/melon intercrop farmers $(75 \%)$ and that on average, maize/melon intercrop farmers were more technically efficient than the sole maize farmers. This implies that sole maize farmers were $31 \%$ inefficient more than the inefficient maize/melon intercrop farmers (25\%). This is in tandem with recent findings [4,15,22]. However, this finding negates another research [23] that in maize-melon mixtures, the sole crop components yielded higher than the corresponding crops in intercropping situation.

Table 2: Distribution of technical efficiency scores of both sole maize and maize/melon intercrop farms.

\begin{tabular}{|c|c|c|c|c|c|c|}
\hline \multirow[b]{2}{*}{ Technical Efficiency Range (\%) } & \multicolumn{3}{|c|}{ Sole Maize } & \multicolumn{3}{|c|}{ Maize/Melon Intercrop } \\
\hline & Frequency & Percentage & Cumulative Percentage & Frequency & Percentage & Cumulative Percentage \\
\hline $21-30$ & 2 & 4.26 & 4.26 & 2 & 4.26 & 4.26 \\
\hline $31-40$ & 1 & 2.13 & 6.39 & 2 & 4.26 & 8.52 \\
\hline $41-50$ & 5 & 10.64 & 17.03 & 2 & 4.26 & 12.77 \\
\hline $51-60$ & 9 & 19.15 & 36.17 & 8 & 17.02 & 29.79 \\
\hline $61-70$ & 6 & 12.77 & 48.94 & 5 & 10.64 & 40.43 \\
\hline $71-80$ & 8 & 17.02 & 65.96 & 5 & 10.64 & 51.07 \\
\hline $81-90$ & 8 & 17.02 & 82.98 & 9 & 19.15 & 70.22 \\
\hline $91-100$ & 8 & 17.02 & 100 & 14 & 29.79 & 100 \\
\hline
\end{tabular}


Annals of Reviews and Research

\begin{tabular}{|c|c|c|c|c|c|c|}
\hline Total & 47 & 100 & & 47 & 100 & \\
\hline Mean & 0.69 & & & 0.75 & & \\
\hline Minimum & 0.28 & & & 0.26 & & \\
\hline Maximum & 1 & & & 1 & & \\
\hline
\end{tabular}

For an average sole maize farmer that operating at the highest level of efficiency, such farmer is saving a cost of $31 \%$ (i.e. $1-(0.69 / 1) \times 100)$. An efficient maize/melon farmer is saving $25 \%$ cost (i.e. $1-(0.75 / 1) \times 100)$. However, majority of sole maize farmers $(51.06 \%)$ had technical efficiencies between $71-100 \%$ while the percentage for the maize/melon intercrop farmers was $59.58 \%$.

\section{Conclusion and Recommendations}

The study brought to fore the differences in level technical efficiency of sole maize and maize/melon intercrop farmers in the study area, more importantly as a result of inefficiencies in the farming system employed. The study revealed that the mean technical efficiency for the maize/melon intercrop farmers was higher than that of the sole maize famers, meaning higher efficiency. Costs of land, labor and implement were the factors affecting the level of sole maize farmers' productivity, while the maize/melon intercrop farmers' productivity was significantly determined by costs of land, labor and capital. Also, land security and extension visit were the major significant inefficiency factors found out to reduce the inefficiencies of maize/melon intercrop farmers in the study area.

Based on the findings of this study, the following were recommended for the farmers in the study area.

1. It is advised that famers in the study area should venture into the intercropping of maize and melon more than sole maize cropping.

2. The rights to land should be strengthened to enable maize/melon intercrop farmers enjoy better technical returns from the land.

3. Also, extension agents should make more visits to the farmers, bringing more innovations and information, to ensure that farmers achieve a higher level of technical efficiency.

\section{References}

1. Ouma, G, Jeruto P (2010) Sustainable horticultural crop production through intercropping: The case of fruits and vegetable crops: A review. Agriculture and Biology Journal of North America 1(5): 1098-1105.

2. Remison SU, Onelemhemhen OP (1999) Effects of maize, okra and rice intercropping with soybean on grain yield min a humid tropical environment. Nigerian Journal of Palm and Oil Seeds 14: 169-175.

3. Tanko L, Mbanasor JA (2006) Comparative analysis of resource productivity in sole and intercropping in Kebbi State, Nigeria. International Journal of Agriculture and Rural Development 7(1): 125132.

4. Chinaka CC, Obiefuna JC (2000) Evaluation of optimum population and biological efficiency of sweet potato/maize intercropping system. In: Law-Ogbomo KE, Ekunwe PA (Eds.) (2011) Economic Yield and
Profitability of Maize/Melon intercrop as Influenced by Inorganic Fertilizer Application in Humid Forest Ultisol. Not Sci Biol 3(4): 66-70.

5. Yusuf O, Sanni SA, Ojuekaiye EO, Ugbabe 00 (2008) Profitability of 'egusi' melon (Critrullus lanatus Thunb. Mansf) production under sole and mixed cropping systems in Kogi State, Nigeria. ARPN J Agric Biol Sci 3(2): 14-18.

6. Poggio SL (2005) Structure of weed communities occurring in monoculture and intercropping of field pea and barley. Agric Ecosystem Environment 109(1-2): 48-58.

7. Fujita K, Offosu-Budu KG (1996) Significance of Inter-cropping in Cropping Systems. In: Ito Katayama OK, Johansen C, et al. (Eds.) Roots and Nitrogen in cropping systems of Semi-Arid Tropics. Japan: JIRCAS International Agricultural Series No. 3, Ohwashi, Tsukuba, Ibaraki, 305: 1-18.

8. Isoken TA (2000) Diagnostic Survey of Soil Management Techniques by Food Crop Farmer. A case study of EDO State, Nigeria. Niger Journal of Soil Sci 12: 22-34.

9. Fakayode BS, Babatunde R0, Ajao R (2008) Productivity analysis of cassava-based production systems in the Guinea Savannah: case study of Kwara State, Nigeria. American Eurasian J Sci Res 3(1): 33-39.

10. Raji JA (2007) Intercropping soybean and maize in a derived savanna ecology. African Journal of Biotechnology 6(16): 1885-1887.

11. Iken JE, Amusa NA (2004) Maize research and production in Nigeria. African Journal of Biotechnology 3(6): 302-307.

12. Kamara AY, Markir A, Ajala SO (2005) Performance of diverse maize genotype under nitrogen deficiency in the Northern Guinea savannah of Nigeria. Experimental Agriculture 41(2): 199-212.

13. Kayode GO, Remison SU (1982) Effect of intra-row spacing and nitrogen on maize in the Southern Guinea savanna zone of Nigeria. Nigeria Agricultural Journal 17(18): 22-31.

14. Okaka VB, Remison SU (1999) Effects of intra-row spacing and fertilization on the performance of melon. Nigeria Agricultural Journal 30: $49-58$

15. Ogunremi OA (2005) Weed control in maize/cassava intercrop. Network for Eco farming in Africa (NECOFA) 7(2).

16. Dimitrios B, Panayiota P, Aristidis K, Sotiria P, Anestis K, et al. (2010) Weed-suppressive effects of maize-legume intercropping in organic farming. International J Pest Management 56(2): 173-181.

17. Haymes R, Lee HC (1999) Competition between autumn and spring planted grain intercrops of wheat (Triticum eastivum) and field bean (Vicia faba). Field Crops Res 62(2-3): 167-176.

18. Ofori F, Stern WR (1987) Cereal-legume intercropping systems. Advance in Agronomy 41: 41-90.

19. Coelli TJ (1994) A guide to FRONTIER version 4.1: a computer program for stochastic frontier production and cost function estimation. Department of Ecnometrics, University of New England, Armidale, Australia, p. 32.

20. Olowa OW, Olowa OA (2010) Sources of technical efficiency among smallholder maize farmers in Osun State of Nigeria. Res J Applied Sci 5(2): 115-122. 
21. Amaza PS, Maurice DC (2005) Identification of factors that influence technical efficiency in rice-based production systems in Nigeria Proceedings of the Workshop on Policies and Strategies for Promoting Rice Production and Food Security in Sub-Saharan Africa, Cotonou Benin, pp. 1-9.

22. Javanmard A, Dabbagh Mohammadi NA, Javanshir A, Moghaddam M, Janmohammadi H (2009) Forage yield and quality in intercropping of

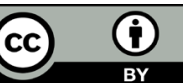

This work is licensed under Creative Commons Attribution 4.0 License

DOI: $10.19080 / A R R .2019 .05 .555657$ maize with different legumes as double cropped. J Food Agriculture and Envir 7(1): 163-166.

23. Law-Ogbomo KE, Ekunwe PA (2011) Economic Yield and Profitability of Maize/Melon Intercrop as Influenced by Inorganic Fertilizer Application in Humid Forest Ultisol. Not Sci Biol 3(4): 66-70.

\section{Your next submission with Juniper Publishers will reach you the below assets}

- Quality Editorial service

- Swift Peer Review

- Reprints availability

- E-prints Service

- Manuscript Podcast for convenient understanding

- Global attainment for your research

- Manuscript accessibility in different formats

( Pdf, E-pub, Full Text, Audio)

- Unceasing customer service

Track the below URL for one-step submission https://juniperpublishers.com/online-submission.php 